\title{
Cause of all Nations: An International History of the American Civil War
}

Review Number: 1843

Publish date: Thursday, 15 October, 2015

Author: Don H. Doyle

ISBN: 978-0-465-02967-9

Date of Publication: 2013

Price: $£ 19.24$

Pages: 400pp.

Publisher: Basic Books

Publisher url: http://www.basicbooks.com/full-details?isbn=9780465029679

Place of Publication: New York, NY

Reviewer: Martin Crawford

Just over a quarter of a century ago, it seemed, you couldn't buy interest in the international history of the American Civil War. American scholars appeared especially uninterested in a subject that, as Don Doyle's splendid new book reveals, is ripe with possibility. Late 20th-century indifference was clearly demonstrated in a volume designed to take the war's historiographical temperature, published by the University of South Carolina Press in 1998. In their introduction to Writing the Civil War, the distinguished editors James M. McPherson and William J. Cooper, Jr. claimed that while 'there are too many specialized subjects for every one to have their place in a single volume of reasonable length', they had nonetheless covered the conflict's 'most significant topics'.(1) The editors identified areas upon which further light could be shed, including the naval war, public opinion, military tactics, Jefferson Davis, sex and sexuality, and the destruction of slavery; but the list failed to include foreign relations which garnered not a single mention in either the introduction or in any of the 12 essays authored by an elite group of Civil War scholars. The war's international impact was conspicuous by its absence from this otherwise valuable overview.

The omission of foreign affairs from Writing the Civil War was a curious by-product of American exceptionalism (and was particularly odd given that one of the editors, James M. McPherson, had already written perceptively on the topic in numerous publications). Fortunately, just as that volume appeared, there were clear signs that interest in the war's international impact had already begun to revive. In that year, Charles Hubbard produced the first dedicated survey of Confederate foreign relations since Frank Owsley's seminal King Cotton Diplomacy, originally published nearly seven decades earlier.(2) Hubbard's volume was followed by important studies by, among others, Howard Jones, Richard Blackett, Duncan Andrew Campbell, and Philip Meyers.(3) In 2010, the University of North Carolina Press confirmed the revived interest with the inclusion of Jones' Blue and Gray Diplomacy: A History of Union and Confederate Foreign Relations in its 'Littlefield History of the Civil War Era' series.(4) Recently, American history's new internationalism has resulted in attempts to understand the Civil War in broader comparative and/or transnational terms (and incidentally move the subject away from its focus upon Anglo-American relations). Brian Schoen's The Fragile Fabric of Union, a major revisionist study that examined the war's global origins through the prism of Old South political economy, appeared in 2009.(5) It was followed in 2010 by an erudite collection on Secession as an International Phenomenon (edited by Don Doyle) and the next year 
by Richard Carwardine and Jay Sexton's The Global Lincoln, a fascinating set of essays that roamed widely across the political, intellectual and geographic landscape in an attempt to pin down its subject's worldwide appeal.(6) Internationalizing the sectional war has now become a brisk trade; a collection derived from a 2011 conference held at the College of Charleston, and published last year as The Civil War as Global Conflict: Transnational Meanings of the Civil War (edited by David T. Gleeson and Simon Lewis), reveals this new determination to expand the discussion beyond familiar horizons.(7) These new approaches are of course to be welcomed; but so too are the efforts at more traditional, less voguish revisionism, exemplified by Brian Jenkins' excellent new biography of Lord Lyons, the often maligned British Minister to Washington during the war. $\underline{(8)}$

In his new book Don Doyle eschews voguishness but is fully attuned to the intellectual currents sustaining this renewed interest in the Civil War's international history. The Cause of All Nations is a narrative triumph. Doyle's research reach is extensive, his writing agile and precise, and the result is that uncommon thing: a volume that speaks equally to specialists and to general readers whose appetite for the sectional war shows no sign of abating. The author has wisely resisted the temptation to provide an encyclopaedic account of the war's foreign impact. The main focus here is on Europe (and by extension Latin America), and in particular Britain and France, the two nations whose support the Federal and Confederate governments were most anxious to enlist. But readers expecting a narrow retelling of the history of Anglo-American and Franco-American relations after 1861 will be disappointed. Doyle's Europe is a large, rambunctious place and he is equally at home in Madrid and the cloistered corridors of the Vatican as in the more familiar environs of Westminster and the Elysee Palace. It is also a Europe that harboured hemispheric ambitions, notably Napoleon's thwarted plans for a Catholic buffer state in Mexico, a catastrophic adventure that Doyle's narrative invests with vivid, newly minted authenticity.

The central theme of The Cause of All Nations is the Civil War as a war of political ideas. Liberals in Europe and beyond identified the fight against secession with their own struggles for democracy and equality; confronting them across the ideological barricades were conservatives and monarchists for whom the American schism portended nothing less than the failure of republicanism and its attendant sins. Within this basic framework, Doyle skilfully tracks the efforts of Union and Confederate diplomats, propagandists and foreign sympathizers to harness European opinion to their respective causes. These campaigns combined 'hard-power' strategies of economic and political coercion with 'soft-power' appeals to fundamental values; the latter approach especially required the sustained manipulation of public discourse on the war's origins and likely outcome. Much of this outline story is familiar; some of it undoubtedly is not, and even seasoned scholars will be invigorated by the author's richly detailed account of public and private diplomacy across the Atlantic divide and by his fresh characterizations of the many well-known and not-so-well-known individuals who, with varying degrees of success and legitimacy, conducted it. Throughout, the author insists that the American Civil War 'really mattered' to the wider world, a view with which historians have not always felt comfortable.

The narrative opens with Guiseppe Garibaldi, who, as everyone knows, was offered the command of the Federal armies in the summer of 1861. Or was he? Doyle's adroit deconstruction of the Garibaldi story makes for compelling reading but the author has a larger purpose. Firstly, he is anxious to highlight the reasons why the Hero of Two Worlds declined the offer of Federal service (command of one not all of the North's armies, as it turned out); and secondly, he uses the story to point up the 'enormous power the press and public opinion were about to play in foreign relations and the vital importance their management would have in the diplomatic duel that was soon to unfold' (p. 26). The source of Garibaldi's refusal can be traced to the question he posed to those seeking to enlist him into the Federal cause. Is this war, he inquired, 'regarding the emancipation of the Negroes or not?' (p. 20). The question would thread itself relentlessly through the international history of the Civil War, and for Union advocates especially was the cause of immense difficulty. For Garibaldi, secession represented a heaven-sent opportunity to pursue emancipation on a potentially hemispheric scale; but for Lincoln's government a war against slavery was not and could not be its prime objective. By the summer of 1862, the war against Southern slaveholders was gradually but inexorably becoming a war against the peculiar institution itself, yet ironically this had the effect of 
encouraging European mediation efforts. When the President set the wheels of emancipation in motion in September 1862, many across the Atlantic were convinced that his action - borne more, they concluded, of necessity than conviction - would result not in the sweet taste of freedom but in bitter servile insurrection or as they often put it, race war, and this would have incalculable consequences for North Atlantic stability and trade, including crucially the production and supply of cotton.

The widely predicted slave rebellion did not occur. Emancipation would soon transform foreign perceptions of the war's character and by January 1863, observes Doyle, 'the cynical criticism of Lincoln's proclamation seemed to be softening' (p. 244). Most intriguingly, Doyle returns to Guiseppe Garibaldi. From his prison cell in Italy, the wounded hero rekindled his support for the Union, now morally enriched by the President's action. On October 5, 1862 crowds of up to a 100,000 people gathered in London's Hyde Park, one of many pro-Garibaldi demonstrations that lit up European radicalism in this period and helped boost liberal optimism about the strength of popular support for the Federal cause. Confederate leaders for their part responded not by proposing concessions on slavery, as British supporters such as the Liverpool merchant James Spence advised, but by embracing the forces of political reaction, notably Pope Pius IX, whose 30year reign Doyle memorably describes as 'a rebellion against everything modern' (p. 262). An 11th-hour attempt to reverse the diplomatic tide by offering emancipation for recognition revealed the desperation of the South's planter leadership. Duncan Kenner's mission was unlikely to succeed; any residual chance was snuffed out by the Confederate representatives in Europe, John Slidell and James M. Mason, who could hardly bring themselves to spell out a proposal that effectively conceded the very argument the slaveholders' republic had been founded to defend. The author is properly scathing about the emancipation initiative. If the South had been willing to end slavery, the New York newspaperman and diplomat John Bigelow later commented, 'there would have been no war, and the Confederate maggot would never have been hatched' (p. 280).

Other historians would narrate the international history of the Civil War differently (although few if any would do it better). Does Don Doyle's approach potentially understate the body of European opinion for whom the transatlantic war was less an ideological struggle than a serious and wholly unwelcome disruption to established routines? Was it possible to be indifferent about the war's outcome? In Britain certainly there was considerable anger at Americans of both stripes for becoming drawn into a damaging conflict that few believed could ever be resolved militarily. There is also arguably too little here about economics and specifically finance. It is ironic that when banks and bankers loom so large in our lives, the role played by finance in the war's international history should remain undervalued. Historians continue to neglect Jay Sexton's impressive 2005 study, Debtor Diplomacy: Finance and American Foreign Relations in the Civil War Era, 1837-1873, in which he describes the enormous power wielded by London-based bankers such as the Barings, the Rothschilds and the Peabodys, whose investment in the emergent capitalist order of the northeastern United States generally predisposed them to favour a Union victory.(9) This aspect of midcentury globalization deserves as much inclusion in the Civil War synthesis as do the more oft-told deeds of, dare one say it, any number of politicians and diplomats.

But such loose thoughts must not deter us from acknowledging Don Doyle's outstanding contribution to 19th-century history. The Cause of All Nations is the most persuasive account we have of the American Civil War's contemporary significance. Authoritative and accessible, it deserves and will surely gain a very wide readership and should encourage a new generation of historians, in the United States and beyond, to pursue further investigations into this most capacious of topics. Whatever else his book achieves, it is now hard to see anyone arguing for the sectional war as an event limited by geography or one in which the issues at stake were in any sense parochial.

\section{Notes}

1. James M. McPherson and William J. Cooper, Jr. eds., Writing the Civil War: The Quest to Understand (Columbia, SC, 1998), p. 4.Back to (1)

2. Charles M. Hubbard, The Burden of Confederate Diplomacy (Knoxville, TN, 1998); Frank Lawrence 
Owsley, King Cotton Diplomacy: Foreign Relations of the Confederate States of America (Chicago, IL, 1931, 1959). Back to (2)

3. Howard Jones, Abraham Lincoln and a New Birth of Freedom: The Union and Slavery in the Diplomacy of the Civil War (Lincoln, NE, 1999); R. J. M. Blackett, Divided Hearts: Britain and the American Civil War (Baton Rouge, LA, 2001); Duncan Andrew Campbell, English Public Opinion and the American Civil War (Woodbridge, 2003); Phillip E. Myers, Caution and Cooperation: The American Civil War in British American Relations (Kent, OH, 2008)Back to (2)

4. Howard Jones' Blue and Gray Diplomacy: A History of Union and Confederate Foreign Relations (Chapel Hill, NC, 2010).Back to (4)

5. Brian Schoen, The Fragile Fabric of Union: Cotton, Federal Politics, and the Global Origins of the Civil War (Baltimore, MD., 2009).Back to (5)

6. Don H. Doyle ed., Secession as an International Phenomenon: From America's Civil War to Contemporary Separatist Movements (Athens, GA, 2010); Richard Carwardine and Jay Sexton eds., The Global Lincoln (Oxford and New York, 2011).Back to (6)

7. David T. Gleeson and Simon Lewis eds., The Civil War as Global Conflict: Transnational Meanings of the American Civil War (Columbia, SC, 2014).Back to (7)

8. Brian Jenkins, Lord Lyons: A Diplomat in an Age of Nationalism and War (Montreal, 2014). Back to $\underline{(8)}$

9. Jay Sexton, Debtor Diplomacy: Finance and American Foreign Relations in the Civil War Era, 1837-1873 (Oxford, 2005). Back to (9)

\section{Other reviews:}

History Today

http://www.historytoday.com/reviews/international-history-american-civil-war [2]

Economist

http://www.economist.com/news/books-and-arts/21640292-why-war-between-north-and-south-mattered-restworld-whole-family [3]

Wall Street Journal

http://www.wsj.com/articles/book-review-the-cause-of-all-nations-by-don-h-doyle-1423260658 [4]

Source URL:https://reviews.history.ac.uk/review/1843

\section{Links}

[1] https://reviews.history.ac.uk/item/136859 [2] http://www.historytoday.com/reviews/international-historyamerican-civil-war [3] http://www.economist.com/news/books-and-arts/21640292-why-war-between-northand-south-mattered-rest-world-whole-family [4] http://www.wsj.com/articles/book-review-the-cause-of-allnations-by-don-h-doyle-1423260658 